\title{
Contribution to assessement of the tourism impact on Landscape
}

\author{
ALEŠ RUDA
}

Masaryk University, Faculty of Education, Department of Geography

\begin{abstract}
Tourism is one of the largest and fastest-growing economic sectors in the world and it has a variety of impacts on the environment and local communities as well. For a long time it was considered as the purest part of human business. Many adverse tourism impacts on landscape have appeared in context of tourism development, therefore sustainable tourism should be taken into consideration. That is why it is necessary to find out limits to maintain the environment as well as tourism, because as it turns out in status quo it does not work as it should do. As the scale of tourism grows, the resources become more unsustainable. Destination with damaged environment loses its attraction and this fact causes increasing of building a new tourist destination mostly on unsuitable places. Mostly visitors and entrepreneurs do not realize that each place does not fit to build all tourist activities. Then the landscape is under the uncontrolled load which weights the environment. But tourism does not have only this dark side. In many regions it is a necessary human activity for further region development. The specific assessment of the tourism impact should bring a closer look on this problem and help to specify which regions are suitable for tourism spreading or not. In realized research focused on selected communities in the Nízký Jeseník Highlands there was the idea to quantify three suggested data sets (specific environmental area value, tourism potential and tourism infrastructure load) necessary for tourism impact assessment. Data sets were evaluated according to points distribution using pair wise comparison and compared based on correlation and regression. Finally the outputs were used for further recommendations.
\end{abstract}

Key words: tourism impact, environmental assessment, tourism potential, tourism infrastructure load

\section{Introduction}

Many adverse tourism impacts on the landscape have appeared in context of tourism development, therefore sustainable tourism should be taken into consideration. According to the World Tourism Organization, sustainable tourism is a tourism that leads to the management of all resources in such a way that economic, social and aesthetic needs can be fulfilled while maintaining cultural integrity, essential ecological processes, biological diversity and life support systems. That is why, it is necessary to find out limits to maintain the environment as well as tourism, because as it turns out in status quo it does not work as it should do. Of course it is very difficult to assess the impact of tourism because it is necessary to consider both sides of the influence. Following paper is focused on evaluating of an environmental potential, tourism 
potential and tourism infrastructure load in order to assess the capacity of the landscape of a small area in context of sustainable tourism planning.

\section{Current state of research}

First of all it is necessary to mention that quality monitoring of tourism influence on the environment is still missing. Therefore it is able to use only actual contributions of accomplished projects or surveys in progress.

In the fact that tourism has spread all over the world in a few decades research history of this well known phenomenon is relatively short. One of the first studies dealing with a negative impact on landscape was published by Meinecke in 1928. He was engaged in monitoring of tourism influence on tree roots in California redwood state park (Cole, 1991). Other beneficial studies developing earlier approaches were works of G. H. Bates who was observing impacts of hard packed soil on vegetation (Cole, 1991). In the 50th and the 60th years of the 20th century a couple of studies informing about negative impacts on animal species appeared. Considering increasing tourism in the 70th of the 20th century a new term - recreational ecology - was published more frequently than ever. A new research group (Recreation Ecology Research Group) began to meet, concern about questions of recreational ecology, compile accessible information and public scientific papers in 1973. According to Gossling (2002) local influences are well explored, nevertheless their classification in a global scale is more difficult.

At present phytocentric studies concerning with characteristics of vegetation and soil work with negative effects of tourism as indicators of tourism impact (Hošek et al., 2003). Observing of ski slopes activity and new ski slope building has became an actual theme mainly in the area of European Alps since the 70th years of the 20th century. Substantive information is given by many studies from Norwegian institutions focused mainly on sustainable tourism.

One of the most important questions asking in protected areas all over the world is assessment of acceptable tourism impact especially determination of sustainable usage of protected areas. Ecological and economic aspect is evident here. But in case of worth destruction sought-after by visitors they will not come back again. This state would be very troubling especially for sustainable development of areas depending on incomes from tourism. Therefore sustainable tourism implementing should be taken into consideration.

Anthropogenic impacts caused by tourism were monitored during 2004-2006 in Český ráj preserve area by Czech scientists. This research was aimed at creation of an overview of intensity load in selected parts of preserve area during various year seasons and impact assessment. This research was based on visitors counting in specific time period. In the same time the Liberec region funded with NISA o.p.s. cooperation objective measuring of tourist destinations in the Liberec region. The central concern of sustainability is realized by scientist in Environment centre and Institution for Environmental studies of Charles University in Prague as well as by other institutions.

Although many studies have been presented worldwide on the field of sustainable tourism only a few of them are based on GIS analysis and consider their outcomes for 
further application in planning and decision making. This approach is still missing in the Czech Republic.

\section{Data sets suggestion}

This paper brings one of possible points of view how to assess tourism impact on landscape in a small area of selected municipalities of the Nízký Jeseník Highlands (figure 1). For further sustainable tourism management in study area it is suitable to assess key criteria in municipalities using pairwise comparison or use map algebra. The first case description follows. Therefore the most important part was to choose specific characteristics and evaluate their indicators. It proved the most valid solution was to use quantitative analysis based on statistical characteristic comparison. Partial results were used to identify municipalities' position for the suggestion of sustainable tourism development strategy (figure 2). The Nízký Jesník Highlands represents the region with insufficient database therefore collecting primary data was very difficult and their selection depended on required indicators and their present. Three data sets (figure 3) gathering necessary indicators were suggested according to available data (Ruda, 2008):

1. Specific environmental area value

2. Tourism potential

3. Tourism infrastructure load

Data of particular task groups and themes within the frame of data sets were applied to municipalities (basic urban areas) as a proportion in municipality area. It enabled to get valid results usable for data classification and point classification system used for evaluating each municipality. Each municipality gets its final value on the basis of combined calculation of proportion, statistical classification with following point distribution and pairwise comparison expressed by task groups, themes and attributes. For better understanding it is needed to explain some used terms.

Necessary terms:

- Task group (for instance protected areas, landscape lines dealing with specific environmental value assessment) is expressed by number value gained as a sum of weighted values coming from individual themes (natural parks, roads etc.) and categories which are weighted using qualified estimation according to their level of importance in study area.

- Theme is represented by a studied features which are applied to each municipality as a proportion in area, it is expressed using indicators in $\mathrm{km} .10 \mathrm{~km}^{-2}$ (line feature), $\%$ (polygon feature) or index value coming from sum calculation.

- Category is represented by individual characteristics necessary for calculation theme value (for example: forest areas in Land use theme).

\section{Specific environmental area value}

Specific environmental area value (SEAV) was suggested as the best solution for identification of environmental area potential. Suggestion and name of this data set 
comes from used data and basic areas represented by municipality. Concept content of environmental value was used with regard to quantification and data set character. Concept specific means application of factual and preselect environmental criteria as well as the term area reflecting application elementary urban areas (municipalities) as a feature into which mentioned data were applied. Two task groups and three themes whose values were calculated on the basis of themes or categories were specified for particular environmental area value assessment (table 1).

Tab. 1 Overview of task groups, themes and categories for SEAV assessment

\begin{tabular}{|c|c|c|c|c|}
\hline 1. Protected areas & $\begin{array}{c}\text { 2. Coefficient } \\
\text { of ecological } \\
\text { stability }\end{array}$ & 3. Land use & $\begin{array}{l}\text { 4. Habitat } \\
\text { Catalogue Natura } \\
2000\end{array}$ & $\begin{array}{l}\text { 5. Landscape } \\
\text { lines }\end{array}$ \\
\hline $\begin{array}{l}\text { small protected } \\
\text { areas (SPA) }\end{array}$ & \multirow{5}{*}{$\begin{array}{l}\text { - forest areas } \\
\text { - water areas } \\
\text { - grasslands } \\
\text { - meadows } \\
\text { and pastures } \\
\text { - built up } \\
\text { and other } \\
\text { areas }\end{array}$} & \multirow{5}{*}{$\begin{array}{l}\text { - forest areas } \\
\text { - water areas } \\
\text { - orchards } \\
\text { - grasslands } \\
\text { - gardens } \\
\text { - arable land } \\
\text { - built up areas }\end{array}$} & \multirow{5}{*}{$\begin{array}{l}\text { - naturally forest } \\
\text { biotopes } \\
\text { - vegetations } \\
\text { of water bodies } \\
\text { and streams } \\
\text { - springs } \\
\text { and mires } \\
\text { - secondary } \\
\text { grasslands } \\
\text { and heath lands } \\
\text { - scrub } \\
\text { - cliff and scree } \\
\text { - mosaic } \\
\text { of biotopes }\end{array}$} & $\begin{array}{l}\text { direct water } \\
\text { stream }\end{array}$ \\
\hline natural parks (NP) & & & & winding stream \\
\hline $\begin{array}{l}\text { territorial system } \\
\text { of ecological } \\
\text { stability (TSES) }\end{array}$ & & & & roads \\
\hline $\begin{array}{l}\text { bird's areas } \\
\text { in Natura } 2000 \text { (BA) }\end{array}$ & & & & cycle tracks \\
\hline $\begin{array}{l}\text { protected deposit } \\
\text { areas (PDA) }\end{array}$ & & & & railways \\
\hline
\end{tabular}

\section{Tourism potential}

Final tourism potential was calculated as a grand total of realization factors and location factors (table 2).

These two factors were given the same weight because of similar correlation according to final tourism potential. Tourism potential assessment is based on Bina's work (2002) and own research. Each of individual factors were calculated as a proportion of municipalities and individually weighted on basis of pairwise comparison.

\section{Tourism infrastructure load}

Considering difficult data taking dealing with counting visitors tourism load was assessed on the basis of tourism infrastructure. This approach does not provide accurate information but it is sufficient for further sustainable tourism planning (Ruda, 2008). On the whole eight themes were assessed: (1) objects of individual recreation, (2) accommodation facilities, (3) road network, (4) railway network, (5) urban areas, (6) tourist tracks, (7) touring by water, (8) catering establishments. Of course they were also weighted in order to distinguish the different level of their 
Tab. 2 Overview of realization and location factors of tourism

\begin{tabular}{|c|c|c|c|}
\hline \multicolumn{4}{|c|}{ TOURISM POTENTIAL } \\
\hline \multicolumn{4}{|c|}{ factors } \\
\hline \multicolumn{2}{|c|}{ Realization factors } & \multicolumn{2}{|c|}{ Location factors } \\
\hline \multicolumn{2}{|c|}{ individual factors } & \multicolumn{2}{|c|}{ individual factors } \\
\hline Accessibility & Applicability & Natural potential & $\begin{array}{c}\text { Cultural - historical } \\
\text { potential }\end{array}$ \\
\hline $\begin{array}{l}\text { 1. Railway stations } \\
\text { (density) }\end{array}$ & $\begin{array}{l}\text { 1. Tourist tracks } \\
\text { (density) }\end{array}$ & $\begin{array}{l}\text { 1. Natural } \\
\text { remarkableness }\end{array}$ & 1. Monumental zone \\
\hline $\begin{array}{l}\text { 2. Bus stations } \\
\text { (density) }\end{array}$ & $\begin{array}{l}\text { 2. Showplaces } \\
\text { (density) } \\
\text { - fishing areas } \\
\text { - tourist tracks } \\
\text { - natural parks } \\
\text { - tourist attractions } \\
\text { - touring by water } \\
\text { - facility of active } \\
\text { tourism } \\
\text { - protection areas }\end{array}$ & $\begin{array}{l}\text { 2. Suitability } \\
\text { for water recreation }\end{array}$ & $\begin{array}{l}\text { 2. Cultural - } \\
\text { historical } \\
\text { monuments }\end{array}$ \\
\hline $\begin{array}{l}\text { 3. Road network } \\
\text { (roading) }\end{array}$ & $\begin{array}{l}\text { 3. Catering } \\
\text { establishment } \\
\text { (density) }\end{array}$ & $\begin{array}{l}\text { 3. Suitability } \\
\text { for forest recreation }\end{array}$ & 3. Cultural facilities \\
\hline \multirow[t]{5}{*}{$\begin{array}{l}\text { 4. Tourist tracks } \\
\text { (density) }\end{array}$} & $\begin{array}{l}\text { 4. Accommodation } \\
\text { facilities }\end{array}$ & $\begin{array}{l}\text { 4. Suitability } \\
\text { for touring by water }\end{array}$ & 4. Church monuments \\
\hline & $\begin{array}{l}\text { 5. Objects } \\
\text { of individual } \\
\text { recreation } \\
\text { (density) }\end{array}$ & $\begin{array}{l}\text { 5. Suitability } \\
\text { for fishing }\end{array}$ & 5. Place of pilgrimage \\
\hline & & $\begin{array}{l}\text { 6. Suitability } \\
\text { for protected areas } \\
\text { visiting }\end{array}$ & 6. Sport attractions \\
\hline & & $\begin{array}{l}\text { 7. Other recreation } \\
\text { areas }\end{array}$ & $\begin{array}{l}\text { 7. Health provision, } \\
\text { wellness }\end{array}$ \\
\hline & & $\begin{array}{l}\text { 8. Suitability } \\
\text { according to relief }\end{array}$ & \\
\hline
\end{tabular}


load in the environment. Necessary to say that using data dealing with numbers of visitors, air pollution caused by means of transport etc. would be more accurate. But in fact of the kind of the research as a part of $\mathrm{PhD}$ thesis options were limited and final data were got with using map sources, inquiry offices and own collecting in study area.

\section{Methods}

Each of mentioned data sets represents for each municipality as a specific value (number) which was count up according to following steps (figure 4).

Here is a list of assessment procedure (explanation in text).

Step 1: calculation of proportion of a feature in municipality area

Step 2: qualified estimation of features weight

Step 3: product (multiplying) of proportion and calculated weight

Step 4: sum of products

Step 5: classification using natural breaks method

Step 6: distributing points from 1-5 to each municipality according to position in intervals mentioned above

Step 7: pairwise preferences and WGM (weighted geometric mean) calculation Saaty's method

Step 8: sum of products of calculated weights and distributed points

Step 9: natural breaks of SEAV into 5 classes

Data of particular task groups and themes were applied to municipalities as a proportion in municipality area (step 1, table 3 ).

Tab. 3 Proportion of specific areas (Protected areas task group) in municipality (SPA - small protected areas, NP - natural parks, TSES - territorial system of ecological stability, BA - birds' areas of Nature 2000, PDA protected deposit areas)

\begin{tabular}{|l|c|c|c|c|c|}
\hline \multirow{2}{*}{\multicolumn{1}{|c|}{ Municipality }} & \multicolumn{5}{c|}{ Proportion in municipality } \\
\cline { 2 - 6 } & SPA & NP & TSES & BA & PDA \\
\hline Bílčice & 0 & 0 & 0.160971 & 0 & 0 \\
\hline Bratříkovice & 0 & 0 & 0 & 0 & 0 \\
\hline Bruntál & 0.0028 & 0 & 0.191093 & 0 & 0 \\
\hline Břidličná & 0 & 0 & 0.464645 & 0 & 0 \\
\hline Budišov nad Budišovkou & 0 & 0 & 0.210657 & 0.196 & 0.010191 \\
\hline
\end{tabular}


It enabled to get valid image for each municipality expressed by a number. But it was necessary to set the final calculation up according to the level of importance. Qualified estimation of features weight and was used in this part of research. Qualified estimation (step 2) was used in the case of setting features hierarchy for themes in the task group - for example protected areas consist of individual themes (example weight: SPA - 3, NP - 2, TSES - 2, BA - 3, PDA - 1). Calculated values were multiplied and summed (steps 3, 4; table 4). Better comprehension gives us pseudocartogram showing proportion of protected areas in municipalities (figure 5).

Tab. 4 Proportion of specific area multiplied by estimated weight within protected areas task group

\begin{tabular}{|c|c|c|c|c|c|c|}
\hline \multirow{2}{*}{ Municipality } & \multicolumn{5}{|c|}{ Proportion $x$ qualified estimation of weight } & \multirow{2}{*}{ SUM } \\
\hline & SPA & $\mathbf{N P}$ & TSES & BA & PDA & \\
\hline Bílčice & 0 & 0 & 0.321942 & 0 & 0 & 0.321942 \\
\hline Bratř́kovice & 0 & 0 & 0 & 0 & 0 & $\mathbf{0}$ \\
\hline Bruntál & 0.0084 & 0 & 0.382186 & 0 & 0 & 0.390586 \\
\hline Břidličná & 0 & 0 & 0.92929 & 0 & 0 & 0.92929 \\
\hline Budišov nad Budišovkou & 0 & 0 & 0.421314 & 0.588 & 0.010191 & $\mathbf{1 . 0 1 9 5 0 5}$ \\
\hline
\end{tabular}

Next steps $(5,6)$ are focused on point evaluation of each studied municipalities in mentioned task groups or themes. Five point evaluations were suggested as a tool for municipality classification. Using statistic method natural breaks (figure 6) helped to classify sums of task groups and themes in municipalities into five intervals and thus enabled to allot points from 1 to 5 where 1 means the lowest and 5 the highest point evaluating. In the case of absent feature there was given zero value (table 5).

Tab. 5 Point evaluation using Natural breaks on the example of SEAV calculating showing first five municipalities according to alphabetical order.

\begin{tabular}{|l|c|c|c|c|c|}
\hline \multirow{2}{*}{\multicolumn{1}{|c|}{ Municipality }} & \multicolumn{5}{|c|}{ Point rating } \\
\cline { 2 - 6 } & prot. areas & $\begin{array}{c}\text { coeff. } \\
\text { of ec. stab. }\end{array}$ & land use & biotopes & $\begin{array}{c}\text { landscape } \\
\text { lines }\end{array}$ \\
\hline Bílčice & 1 & 3 & 4 & 2 & 3 \\
\hline Bratř́kovice & 0 & 1 & 0 & 1 & 1 \\
\hline Bruntál & 1 & 2 & 3 & 2 & 3 \\
\hline Břidličná & 2 & 3 & 4 & 3 & 4 \\
\hline Budišov nad Budišovkou & 2 & 3 & 4 & 3 & 4 \\
\hline
\end{tabular}


Saaty's method (Saaty, 1980) using analytic hierarchy process enables to estimate pairwise preferences expressed on a ratio scale (step 7). The Analytic Hierarchy Process (AHP) is a systematic procedure for representing the elements of a multicriteria decision maker problem, hierarchically. A decision problem is broken by means of AHP into smaller parts and then decision makers lead through a series of pairwise comparison judgements to express the relative intensity of the impact of the elements in the hierarchy. It means criteria were compared to each other using 1-9 point scale. If a criterion $A$ is more significant than $B, A$ will get according to the level of significance value 1-9 and B will be expressed in ratio 1:A value (table 6). Finally weighted geometric mean was calculated to each of studied elements that enable to provide a field for other valid mathematical operation (table 4). In the pairwise comparison method, Saaty's consistency test is performed to ensure that the decision maker is being neither random nor illogical in his or her pairwise comparisons. Saaty suggested that the consistency ratio should be less than or equal to 0.1 .

Tab. 6 Pairwise preferences and WGM calculation using Saaty's method on the example of SEAV

\begin{tabular}{|l|c|c|c|c|c|c|c|}
\hline $\begin{array}{c}\text { thematic } \\
\text { elements }\end{array}$ & $\begin{array}{c}\text { protected } \\
\text { areas }\end{array}$ & biotopes & $\begin{array}{c}\text { coefficient } \\
\text { of eco. stab. }\end{array}$ & land use & $\begin{array}{c}\text { landscape } \\
\text { lines }\end{array}$ & GM & WGM \\
\hline $\begin{array}{l}\text { protected } \\
\text { areas }\end{array}$ & 1 & 2 & 3 & 3 & 4 & 2.352158 & $\mathbf{0 . 3 8 5}$ \\
\hline biotopes & $1 / 2$ & 1 & 2 & 3 & 4 & 1.643752 & $\mathbf{0 . 2 6 9}$ \\
\hline $\begin{array}{l}\text { coefficient } \\
\text { of eco. stab. }\end{array}$ & $1 / 3$ & $1 / 2$ & 1 & 2 & 4 & 1.059224 & $\mathbf{0 . 1 7 4}$ \\
\hline land use & $1 / 3$ & $1 / 3$ & $1 / 2$ & 1 & 3 & 0.698827 & $\mathbf{0 . 1 1 4}$ \\
\hline $\begin{array}{l}\text { landscape } \\
\text { lines }\end{array}$ & $1 / 4$ & $1 / 4$ & $1 / 4$ & $1 / 3$ & 1 & 0.349414 & $\mathbf{0 . 0 5 7}$ \\
\hline
\end{tabular}

Apparently the biggest weight was given in context of natural worth to protected areas the lowest level of importance is evident at landscape lines.

Values given in the 6th step were within each thematic element (task groups and themes) in municipalities multiplied with calculated weight (WGM) and subsequently summed. Now each municipality is represented by a number reflecting its specific environmental area value (step 8, table 7).

Considering greater clarity municipalities were following SEAV classified into five intervals with using natural breaks classification method (step 9). Determined classes were according to other data sets given following description: (1) very low - (2) low (3) medium - (4) high - (5) very high value. 
Tab. 7 Final assessment of SEAV (PA - protected areas, KES - coefficient of ecological stability)

\begin{tabular}{|c|c|c|c|c|c|c|c|}
\hline \multirow{2}{*}{ Municipality } & \multicolumn{5}{|c|}{ Points multiplied by weight } & \multirow{2}{*}{$\begin{array}{l}\text { SEAV } \\
\text { value }\end{array}$} & \multirow{2}{*}{$\begin{array}{l}\text { interval } \\
\text { description }\end{array}$} \\
\hline & PA & KES & LANDUSE & BIOTOPES & LINES & & \\
\hline Bílčice & 0.385 & 0.522 & 0.456 & 0.538 & 0.171 & 2.072 & high \\
\hline Bratříkovice & 0 & 0.174 & 0 & 0.269 & 0.057 & 0.5 & very low \\
\hline Bruntál & 0.385 & 0.348 & 0.342 & 0.538 & 0.171 & 1.784 & low \\
\hline Břidličná & 0.77 & 0.522 & 0.456 & 0.807 & 0.228 & 2.783 & high \\
\hline Budišov nad Budišovkou & 0.77 & 0.522 & 0.456 & 0.807 & 0.228 & 2.783 & high \\
\hline
\end{tabular}

\section{Results}

Now we have values of three data sets for each municipality which represents dominant variables for following assessment. Individual couples were put through correlation analysis what enables to determine the measure of interdependence. Correlation between tourism infrastructure load and tourism potential (correlation 0.67) showed up weak but in the frame of examined data sets the most provable interdependence. Using linear regression it is possible to see municipality distribution according to interlay regression line (figure 7). For bigger validity $95 \%$ confidence interval was defined. The $95 \%$ confidence interval is the area that has a $95 \%$ chance of containing the true regression line. The confidence interval enabled to mark 22 municipalities in which we can suppose distributed load. Municipalities founded above the $95 \%$ confidence interval point out that the tourism load is inadequate to tourism potential, while these founded above the $95 \%$ confidence interval predicate of possible reserve in tourism potential. These results can be put into connection with environmentally precious areas and show for instance highly loaded biotopes (figure 8). Figure 5 gives us a possibility to gather similar municipalities with identical intention on the field of sustainable tourism development.

Finally we have data for further analysis including negative tourism impacts detecting, defining possible sustainable types of tourism, infrastructure planning etc. Researched municipalities can be gathered using cluster analysis into typological regions and then they can share the same thought in sustainable tourism planning and writing projects asking for European funds subvention. Regional tourism potential disparities assessment within municipalities is other way how to use final results mainly during the process of strategic planning. They can make agreement on the field of tourist attractions supporting or tourism infrastructure improving. In relation to regional disparities assessment authorities can use partial results mainly those dealing with tourist tracks to increase building information centres and boards which are still missing. 


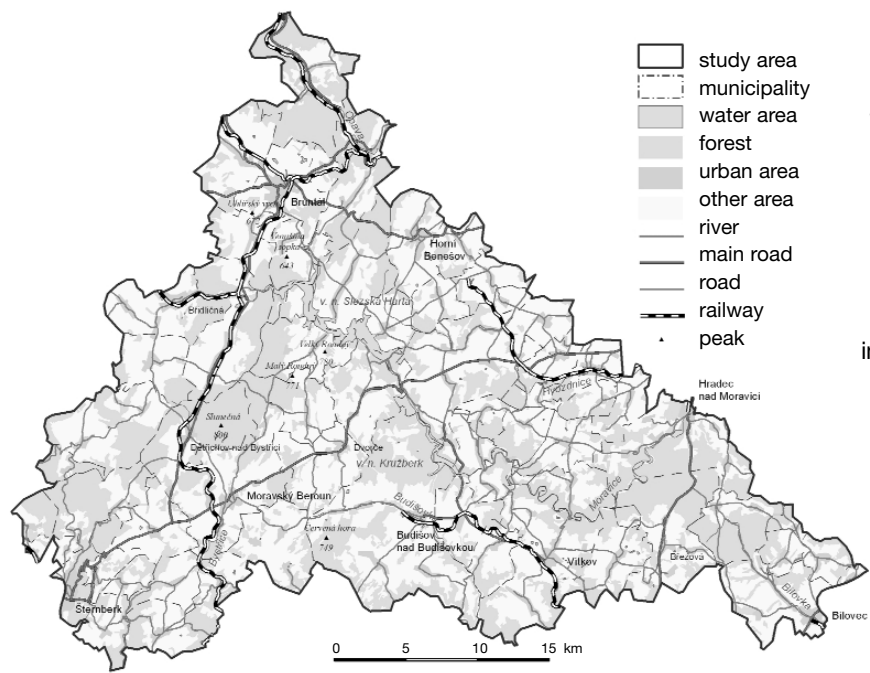

Study area location in the Czech Republic

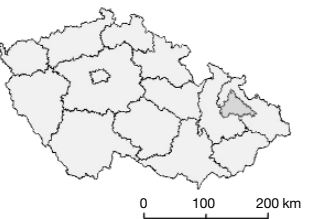

Study area location in the Nízký Jeseník Highlands

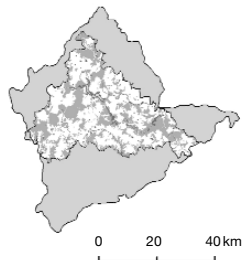

Fig. 1 Study area of the Nízký Jeseník Highlands

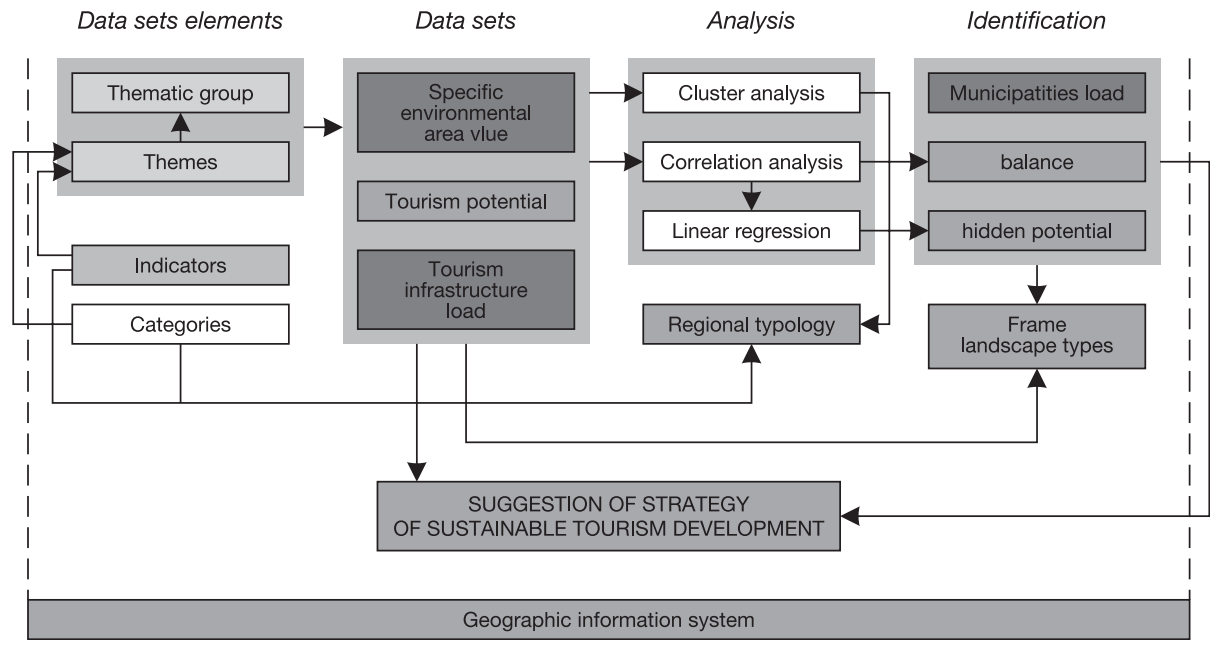

Fig. 2 Scheme of data organization and utilization 


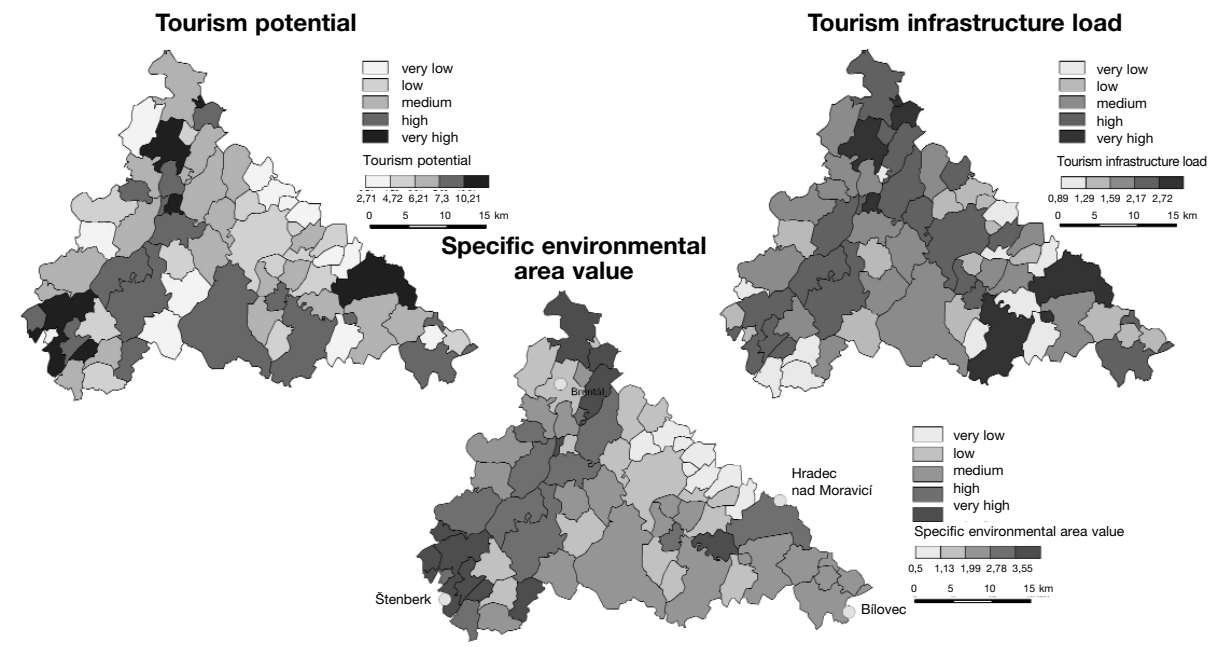

Fig. 3 Data sets thematic visualization

I. Point classification according to sum of weighted values

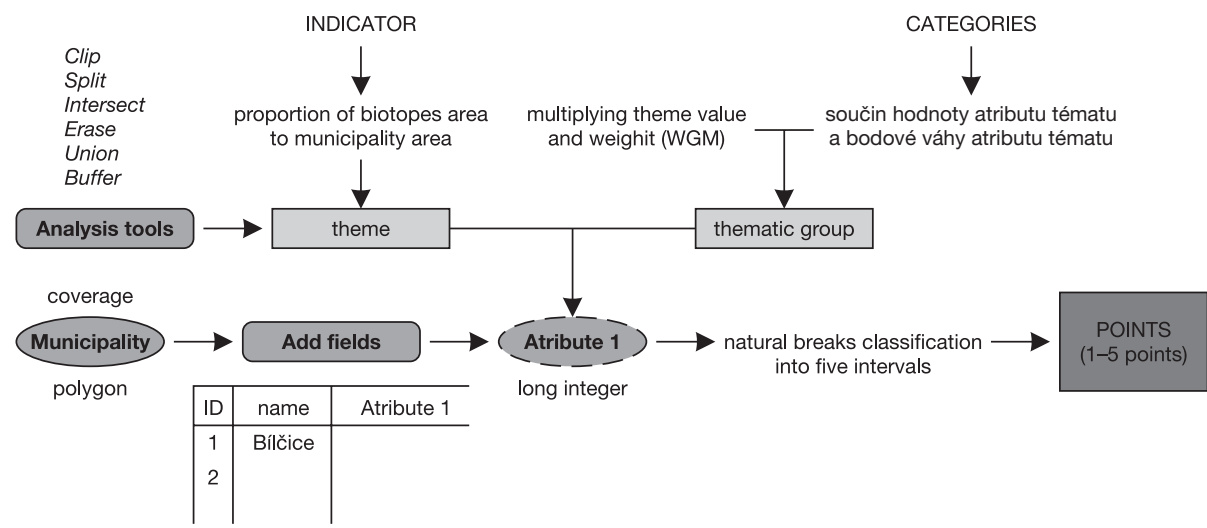

II. Calculation of specific value on the example of Specific environmental area value (SEAV) data set

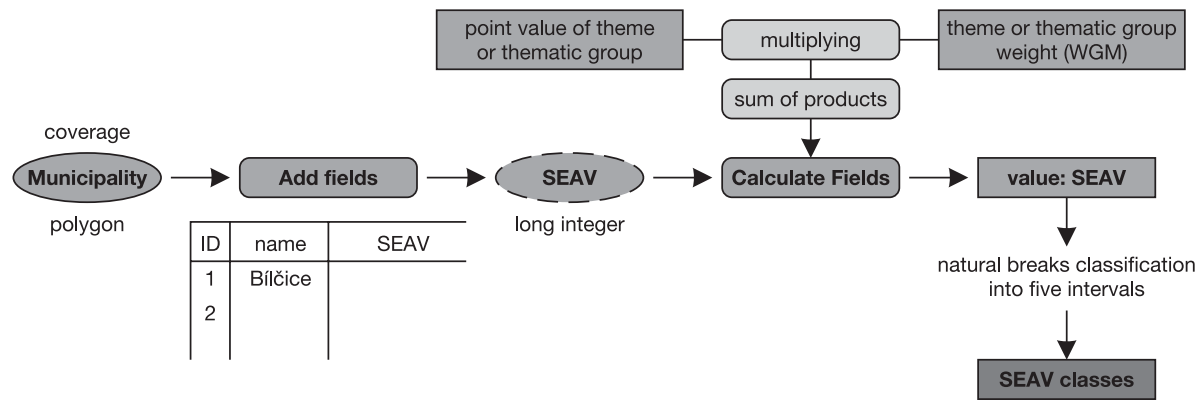

Fig. 4 Scheme of assessment procedure 


\section{Proportion of protected areas in municipalities}

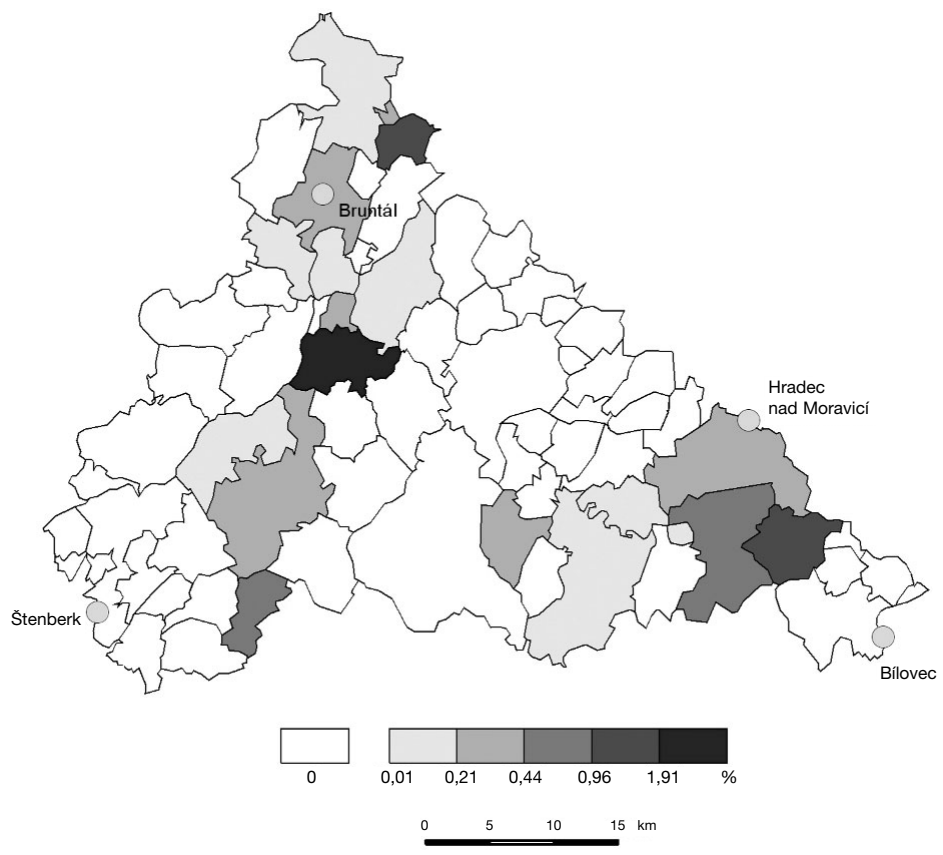

Fig. 5 Pseudocartogram showing proportion of protected areas in municipalities

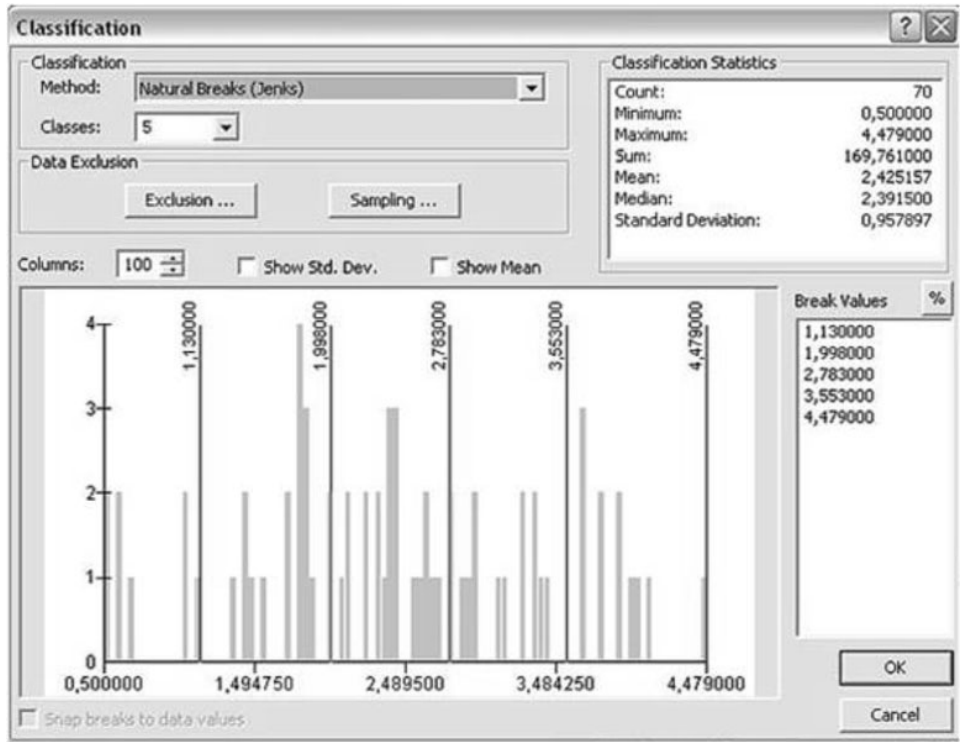

Fig. 6 Break values in classification method using natural breaks 


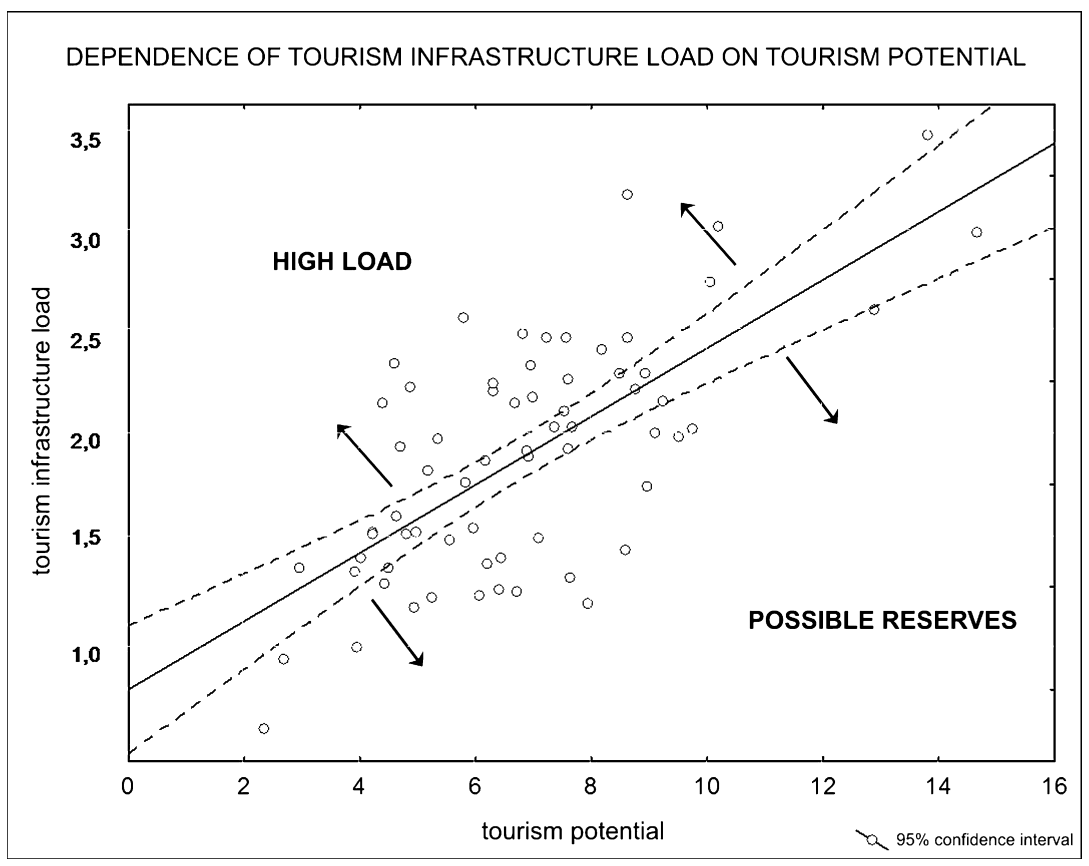

Fig. 7 Dependence of tourism infrastructure load on tourism potential (linear regression)

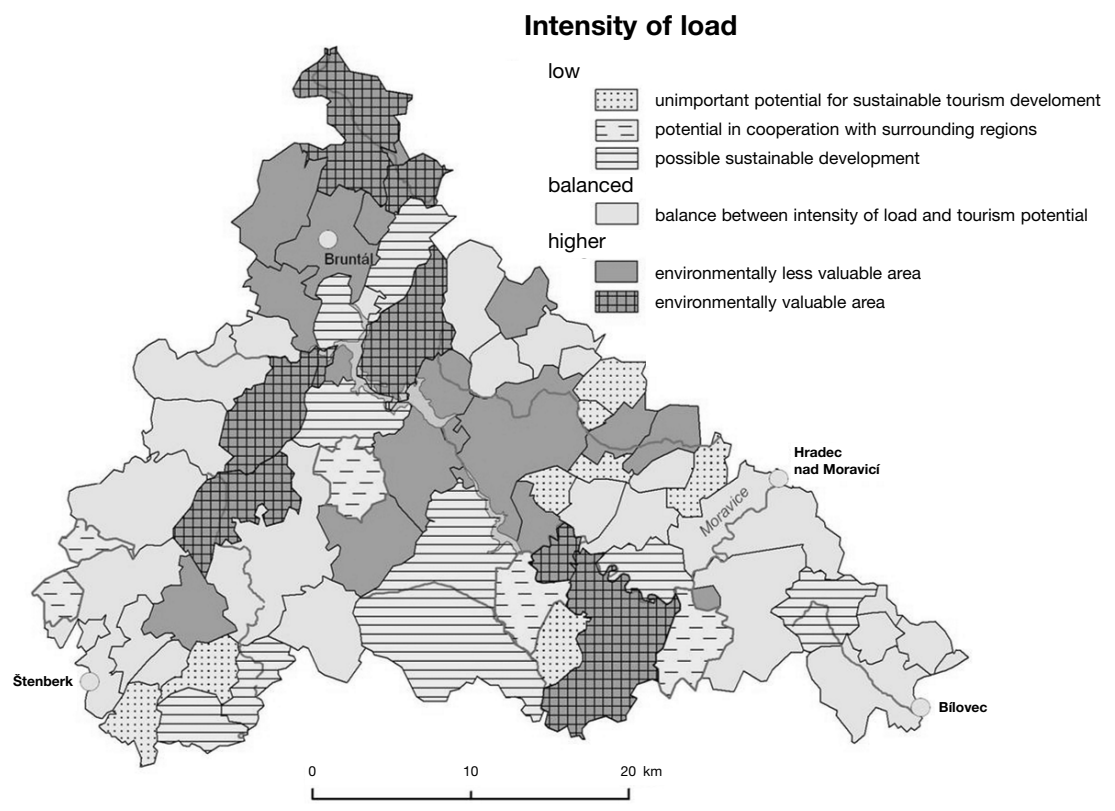

Fig. 8 Tourism infrastructure load in relation to tourism potential on the background of environmentally precious areas 


\section{References}

BÍNA, J. (2002): Hodnocení potenciálu cestovního ruchu v obcích České republiky. Urbanismus a územní rozvoj, roč. 5, č. 1, p. 2-11.

COLE, D., KNIGHT, R., (1991): Wildlife Preservation and Recreational Use: Conflicting Goals of Wildland Management in Recreational Impacts on Wildlife in Wildlands. Rocky Mountain Research Station, Fort Collins.

GÖSSLING, S., (2002): Global environmental consequences of tourism. Global Environmental Change, 12, p. 283-302.

HOŠEK, J. et al. (2003): Vliv rekreačního využití na stav a vývoj biotopů ve vybraných VCHÚ Zpráva o řešení projektu za rok 2003. VaV/620/15/03. Hořovice

International Council for Local Environmental Initiatives http://www.iclei.org/index.php?id=iclei -home\&no_cache $=1$

RUDA, A., (2008): Hodnocení vlivu cestovního ruchu na krajiny Nízkého Jeseníku metodami GIS. [Disertační práce] Ostravská univerzita v Ostravě, Přírodovědecká fakulta, Katedra fyzické geografie a geoekologie.

SAATY, T. L. (1980): The analytic hierarchy process. New York, McGraw-Hill.

\section{Résumé}

\section{Příspěvek k hodnocení vlivu cestovního ruchu na krajinu}

Článek je zaměřen na posouzení dopadu cestovního ruchu na životní prostředí. Přináší bližší pohled na tento problém a definje oblasti, které pro turistiku jsou vhodné a které nikoliv. Výzkum je zaměřen na specifické oblasti životního prostředí, hodnoty potenciálu cestovního ruchu a zatížení infrastruktury cestovního ruchu, které jsou potřebné pro posouzení dopadů cestovního ruchu. Pro testování byly vybrány obce v oblasti Nízkého Jeseníku.

RNDr. Aleš Ruda, Ph.D. Department of Geography Faculty of Education Masaryk University Poř́čč 7 60300 Brno e-mail:ruda@ped.muni.cz. 